\title{
Strategy Formulation of Balek Angin Lake as an Ecotourism Attraction to Support Sintang Regency's Sustainable Development Program
}

\author{
Kamaludin ${ }^{1}$, Antonius ${ }^{1}$, Viktor Emanuel ${ }^{2}$, Nikodimus ${ }^{3}$, Markus Sinaga ${ }^{4}$, Hendra Setiawan $^{5 *}$ \\ ${ }^{1}$ Forestry Study Program, Faculty of Agriculture, University of Kapuas, Sintang, Indonesia \\ ${ }^{2}$ Law Study Program, Faculty of Law, University of Kapuas, Sintang, Indonesia \\ ${ }^{3}$ Public Administration Study Program, Faculty of Social and Political Studies, University of Kapuas, Sintang, Indonesia \\ ${ }^{4}$ Agrotechnology Study Program, Faculty of Agriculture, University of Kapuas, Sintang, Indonesia \\ ${ }^{5}$ Biology Education Study Program, Faculty of Teaching Training and Education, University of Kapuas, Sintang, Indonesia
}

\begin{abstract}
This study aimed to explore the strengths and challenges in formulating a strategy to support the development of the Balek Angin Lake area under the scheme of Sintang Lestari (Sintang sustainable development protocols). This research was carried out in May and June 2019, where field visits focused around the site of Balek Angin Lake located in Akcaya I and Jerora Satu Villages in Sintang subdistrict of Sintang Regency, West Kalimantan Province. This research used a descriptive-quantitative approach. The study uses questionnaires to 10 representative informants, in-depth interviews, and field observations in data collection. Data were analyzed descriptively and SWOT analyses were used to formulate the development strategy. The results of this study show some strengths supporting the development of the area as an ecotourism site, i.e. undisturbed ecosystems, well-protected fish both in quantity and species diversity, the existence of regulation protecting lakes issued by the head of local government (Sintang Regent), and the existence of local nongovernmental organization whose concern in nature protection of Balek Angin lake and upstream of Jemelak River. The main challenge, however, includes the widening business area managed by local residents, such as sand mining, plantation and settlement, disposals from households leading into the lake, and the decrease of household income as the result of the decrease of the price of Sintang's primary commodities. SWOT analyses result in $2.779: 2.203$, which means a horizontal integration strategy where collaboration among different stakeholders is needed. The strategy to develop Balek Angin Lake as an ecotourism site includes the enhancement of the ecosystem through protecting the upstream-downstream area, collaboration of local community and local government through the integration of local community, local NGO, local government, funding NGO, local academia and other environment-conscious stakeholders.
\end{abstract}

Keywords: Ecotourism, Sintang, strategy.

\section{INTRODUCTION}

The regency of Sintang is located in West Kalimantan Province, covering an area of 21.635 $\mathrm{km}^{2}$. Sintang has a unique landscape ranging from tropical forests, watersheds, peat forests, granite hills, and so forth [1]. This kind of landscape has become one of the factors supporting the plan for the economic development of the region under the scheme of Sustainable Regency - a network of regencies under the organization called Lingkar Temu Kabupaten Lestari (LTKL) as an effort toward sustainable development. The primary themes covered in the forum are social forests, agrarian reforms, clean energy and electrification, forest and peatland fire prevention, sustainable commodities, conservation and restoration, waste management, and disaster resilience and management.

\footnotetext{
* Correspondence address: Hendra Setiawan

Email : hendra_setiawan09@yahoo.com

Address : Faculty of Teaching Training and Education, University of Kapuas, Sintang, 78611
}

The development of sustainable districts requires changes in the attitude of the farming community in Sintang district to change the pattern of agriculture and harvesting natural products to be more environmentally friendly. The community must still be able to get the maximum benefits from nature while still paying attention to the preservation of nature $[2,3,4]$. One way to improve the economy of the community is to develop Ecotourism $[5,6]$.

Ecotourism is a concept of developing ecofriendly tourism where local communities are given a primary role to manage it. The main points in ecotourism are environmental conservation, economic development, and community empowerment [4,6]. Ecotourism development is generally carried out in protected areas owned by local communities who still hold closely their customs and culture [7].

The development of protected lake-based ecotourism has been developed in various regions. The development of lake tourism in the Kamipang Region, Central Kalimantan is an example of tourism based on the attractiveness of natural potential and the uniqueness of 
culture and traditional arts [8]. The development of environmentally friendly tourism requires the willingness of tourists to pay the cost of improving the quality of nature, a condition where age, level of education, income, and the number of family dependents have a strong influence on the decision $[9,10]$. According to tourism profile in Sintang and the surrounding areas, there is a willingness from the tourists to pay when visiting a tourism site as long as it is at a low cost.

One of the potentials for the development of ecotourism in the Sintang Regency is Balek Angin Lake, located in Akcaya 1 and Jerora Satu villages of Sintang Regency. This lake is one of the 11 lakes deemed protected by the Sintang Regent Regulation No. 88 of 2018 concerning sustainable lake management in Sintang District. Among the main important points in this regulation is that lake management can be carried out by local communities by taking care of environmental aspects.

Balek Angin Lake is currently under the managementof a local non-governmental organization (NGO), namely Jemelak Lestari (JELAS). This NGO aims at managing the lake with the concept of togetherness and community empowerment, which preserving the lake's ecosystem becomes its major concern. However, until now, there has been no development strategy related to ecotourism development of the lake. This study aims to determine the strengths of Balek Angin Lake ecotourism objects and to further formulate a development strategy to support the Sintang Lestari Regency program.

\section{MATERIALS AND METHOD}

Study area

This research was conducted in the area of Balek Angin Lake, Akcaya 1 and Jerora Satu Villages, Sintang Subdistrict, Sintang Regency, West Kalimantan Province (Fig. 1) in MaySeptember 2019. Balek Angin Lake is a group of lowland lakes that are divided into several small bodies of water. The total area of the lake and its buffer zone is $\pm 69 \mathrm{Ha}$. The water of this lake is reddish, typical of the water in the peat area. The water level is strongly influenced by the flow of rainwater and the flow of the Jemelak River. This change in water level affects the types of animals and plants that grow in the lake area.

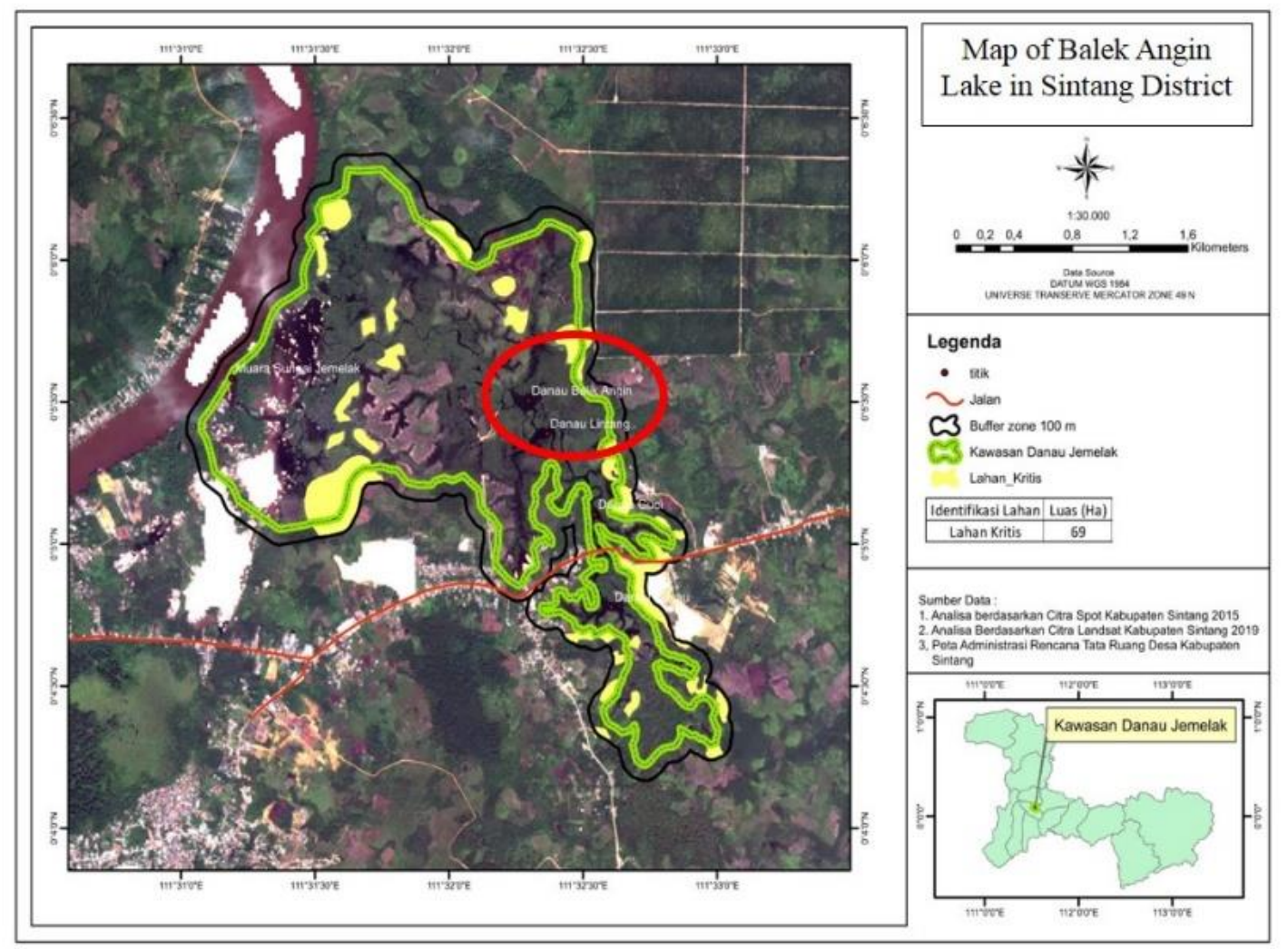

Figure 1. Site map of Balek Angin Lake. Source: Regional Development Planning Agency of Sintang District, 2019. 


\section{Data collection and analysis}

This study is descriptive quantitative research. The data were obtained through indepth interviews, questionnaires, and field observations $[6,11]$. The informants involved in the In-depth interviews were selected based on the purposive sampling technique based on the selection of informants' knowledge and experience regarding policy formulation in the village level. The total number of informants involved was ten people consisting of the Headman of Akcaya, Headman of Jerora Satu, three staffs of the Kelurahan Akcaya, three staffs of Jerora Satu village, the Chair of the NGO JELAS and his collage in JELAS from Jerora Satu Village. Interviews were conducted with each individual. For the Headman and staff of Akcaya, interviews were conducted at their office during working time. $I t^{\prime}$ is also the same as the Headman and staff of Jerora Satu village, the interview was conducted at the village office. Whereas the Chairperson and member of the JELAS NGO were conducted in chairperson's private home.

Data from the interviews were then analyzed qualitatively and presented descriptively. In addition to in-depth interviews, the informants involved were also asked to fill out a questionnaire that was used to collect quantitative data for the SWOT analysis. This questionnaire consists of indicators of strengths, weaknesses, opportunities, and threats in the development of the ecotourism of Lake Balek Angin.

The results of the questionnaire were then analyzed using the Internal Factor Summary Analysis (IFAS) -External Factor Summary Analysis (EFAS) [12]. The preparation of IFAS-EFAS uses the weight, relative, and rating calculations to produce a weighted score based on Rangkuti [12], which was then entered into the IFAS-EFAS matrix table to determine the strategy to be taken [12-14]. Field observation was also used to confirm in-depth interviews and questionnaire data accurately. The results of in-depth interviews, questionnaires, and also field observations were then used to develop a strategy for the development of the ecotourism of Lake Balek Angin [11].

\section{RESULT AND DISCUSSION}

Competitiveness and Challenge of Balek Angin Lakeas tourism attractions

The main tourist attraction in Balek Angin Lake is a seasonal lake ecosystem with all types of biodiversity and culture. The results of in- depth interviews and field observations showed that there were several advantages of Balek Angin Lake ecotourism objects. The main advantage was that the lake ecosystem is still maintained by the provenance of animals and plants native to the river.

Interview with NGOs indicated various types of freshwater fish are still survive, such as Toman (Channa micropeltes), Lais (Kryptopterus bicirrhis), Baung (Mystus nemurus), Tapah (Wallago attu), Catfish (Clarias nieuhofii), Gabus (Channa striata), Tengadak (Barbonymus schwanenfeldii), Biawan (Helostoma temmincki), Seluang (Rasbora spp.) and Kaloi (Osphronemus goramy). These fish species are one of the potential tourist attractions that can be developed in Balek Angin Lake. The attraction that can be developed is fishing ecotourism in nature by using a canoe to the middle of the lake, and then the catch can be cooked on the banks of the lake while enjoying unique natural surroundings.

This type of activity also includes relaxation tourism, where the target tourists are office workers from Sintang City who on weekends, will travel outside with one of the potential destinations is Balek Angin Lake. However, almost all fish species in the world, including freshwater fish in Kalimantan, are decreasing because of overexploitation for consumption $[15,16]$. Excessive cathing of fish is one of the main challenges in the development of Balek Angin Lake ecotourism. The management of the site needs to control the number of fish that being caught by either tourists or fishermen who come.

As for plant species, in the area of Balek Angin Lake, there are plants species such as Putat (Barringtonia acutangula (L.) Gaertn.), Ubah Merah (Eugenia spp.), Ubah Putih (Eugenia spp.), Terinak (Shorea seminis), Kawi (Shorea balangeran), and Tembesuk (Fagraea fragrans). These types of plants are plants that are resistant to the ever-changing of the lake's water level [17]. Some of these plants are used by aquatic animals as nests and foraging. It is similar to the function of coral reefs in the sea, but the place to live in this case is the dead skin from stems and twigs, especially in the Putat plant species.

Putat has cork-like bark that is broken and hollow. Also, in several other lake ecosystems such as in Lake Sentarum, Kapuas Hulu Regency, this Putat plant species has been developed as a natural honeycomb. The flower of Putat is one of the favorite foods of honey bees and can 
produce honey with superior quality [18]. This potential can then be developed into one of the new tourist attractions that are managed jointly by the community. Honey produced from this Putat plant can be one of the flagship attractions of Balek Angin Lake.

The types of animals and plants in Balek Angin Lake interact with each other and produce complex ecosystems (Fig. 2). This ecosystem may later be developed simultaneously as a leading tourist attraction. It is in line with Setiawan [11] that explained the development of superior animal and plant species can be used as ecotourism flagship species. The development and good management of flagship species will make ecotourism sustainable.

The existence of a non-government organization called JELAS (Jemelak Lestari/ Sustainable Jemelak) is also an advantage of developing Balek Angin Lake ecotourism. The NGO is a team of residents living around Balek Angin Lake, and they depend on the existence of the Balek Angin Lake ecosystem, as most of them are fishermen. The relationship between people who manage nature and nature forms a strong bond, especially in environmental protection and its sustainable use [19].

The Government of Sintang Regency provides full support for the development and sustainable management of protected lakes. It is stated in the development of access roads to the Balek Angin Lake, support the operation of local NGOs (JELAS) and also creating the regent regulation to manage the lake sustainably. It is stated in the Sintang Regent Regulation No. 88 of 2018 regarding Sustainable Lake Management in Sintang District. This regulation is an advantage of Balek Angin Lake being an ecotourism destination. Ecotourism is expected to be a solution to improve the economy of the community around the lake by not damaging the lake's ecosystem [5].

However, the weakness of the development of Balek Angin Lake as one of the ecotourism destinations in the Sintang Regency is the threat of ecosystem degradation from the expansion of community plantation areas, settlements, and household waste flow that can flow into the lake. It can be seen in the reduced population of big fish in the lake. Based on interviews with locals, in the 2000's the population of big fish in the lake is considerable. But now, it's hard to find a big fish in lake. Ecosystem damage, which is one of Balek Angin Lake ecotourism attractions, will adversely affect the level of tourist satisfaction, which will ultimately reduce the number of tourists [20]. Therefore, the management strategy of Danau Balek Angin must be carried out as well as possible.
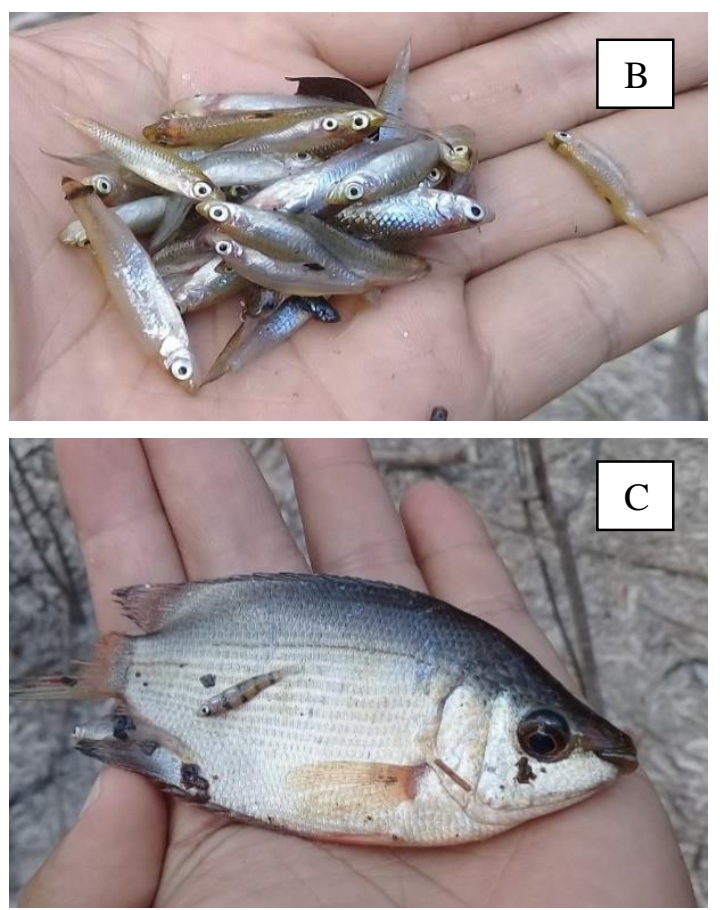

Figure 2. Types of plants and animals in Balek Balek Lake (A) Putat (Barringtonia acutangula (L.) Gaertn.), (B) Seluang (Rasbora spp.), (C) Biawan (Helostoma temmincki) 
The main threat in the development of ecotourism in the Sintang Regency is the tendency of orienting water tourism alike towards mass tourism Sintang citizens preferred a place with a crowd and modern attraction. This reason makes ecotourism is not a cool place to visit. This water tourism is in the form of a swimming pool and water park, which is located in the city center. This threat can become an opportunity if the management of Balek Angin Lake ecotourism can provide attractions that are more interesting than the existing objects. It has happened in several places where ecotourism has taken over conventional tourists because of better management $[7,20,21]$.

Besides, the decline in public income is also a threat to the development of Balek Angin Lake ecotourism. Declining prices of staple commodities in the Sintang Regency, such as falling prices for natural rubber, palm oil, and pepper, make people reluctant to visit places, which requires money, and this must be managed properly so that tourist interest is maintained. One of them is holding several ecotourism events by cooperating with sponsors to finance it so that it can be done for free. Ecotourism management can also work with NGOs who can provide funding assistance so that the management of the site does not necessarily collect fees from visiting tourists and the number of tourists per day can be limited.

\section{Strategy in Developing Balek Angin Lake as an Ecotourism Destination}

Ecotourism development strategy formulation was based on a SWOT analysis of the data obtained from questionnaires, interviews, and observations. SWOT results were generated through SWOT analysis on a questionnaire, which is then processed using Internal Factor Summary Analysis (IFAS) and External Factor Summary Analysis (EFAS). IFAS and EFAS calculation results are shown in the following Table 1 and 2.

Table 1. Internal Factors Analysis Summary (IFAS) Matrix

\begin{tabular}{|c|c|c|c|c|}
\hline Internal Factors & Weight & Relative & Rating & Weighted Score \\
\hline \multicolumn{5}{|l|}{ Strengths } \\
\hline The lake ecosystem is still maintained & 3.6 & 0.103 & 3.5 & 0.360 \\
\hline Many types of consumable fish are native to the lake & 4.3 & 0.123 & 3.8 & 0.467 \\
\hline $\begin{array}{l}\text { Balek Angin Lake is among the protected lake based on Sintang regent } \\
\text { regulation No. } 88 \text { in } 2018\end{array}$ & 3.7 & 0.106 & 3.5 & 0.370 \\
\hline Existence of local NGO to manage the lake & 3.3 & 0.094 & 3.2 & 0.302 \\
\hline Community's willingness to protect the lake & 3.5 & 0.100 & 2.4 & 0.240 \\
\hline \multicolumn{5}{|l|}{ Weaknesses } \\
\hline The lake has not been managed in accordance with ecotourism principles & 3.1 & 0.089 & 1.6 & 0.142 \\
\hline Community awarness in protecting the lake is still low & 3.5 & 0.100 & 1.4 & 0.140 \\
\hline Waste of household activity flows into the lake & 3.5 & 0.100 & 2.8 & 0.280 \\
\hline The lack of people involved in lake management & 3.4 & 0.097 & 2.1 & 0.204 \\
\hline Lack of facilities and infrastructure on the lake & 3.1 & 0.089 & 3.1 & 0.275 \\
\hline Total Score & 35 & & & 2.779 \\
\hline External Factors & Weight & Relative & Rating & Weighted Score \\
\hline \multicolumn{5}{|l|}{ Opportunity } \\
\hline $\begin{array}{l}\text { The local government, through the tourism office, supports the } \\
\text { development of lake tourism }\end{array}$ & 3.50 & 0.109 & 3.7 & 0.404 \\
\hline $\begin{array}{l}\text { The distance between Danau Balek Angin and the city center is closer } \\
\text { than other natural attractions }\end{array}$ & 3.10 & 0.097 & 3.2 & 0.310 \\
\hline Increasing number of local and foreign tourists in Sintang Regency & 3.10 & 0.097 & 2.0 & 0.194 \\
\hline Many tourism events are held and supported by the local government & 3.30 & 0.103 & 1.6 & 0.165 \\
\hline $\begin{array}{l}\text { Support from NGOs and academic institutions for the development of } \\
\text { ecotourism }\end{array}$ & 3.50 & 0.109 & 1.2 & 0.131 \\
\hline \multicolumn{5}{|l|}{ Threats } \\
\hline Expansion of illegal gold, sand, and limestone mining areas & 3.80 & 0.119 & 2.1 & 0.249 \\
\hline Expansion of oil palm and rubber plantations around the lake & 3.22 & 0.101 & 1.3 & 0.131 \\
\hline Expansion of residential areas to the lake area & 2.80 & 0.087 & 2.4 & 0.210 \\
\hline $\begin{array}{l}\text { Number of water attractions based on mass tourism (Swimming pool, } \\
\text { water park) }\end{array}$ & 2.80 & 0.087 & 2.3 & 0.201 \\
\hline $\begin{array}{l}\text { The decline in community income due to the decline in the value of } \\
\text { agricultural and plantation commodities }\end{array}$ & 2.90 & 0.091 & 2.3 & 0.208 \\
\hline Total Score & 32.02 & & & 2.203 \\
\hline
\end{tabular}


The results of the SWOT analysis based on the distributed questionnaire on IFAS showed the highest value on the strength factor is the aspect of the number and type of consumable fish native to the lake with a value of 0.467 and followed by the status of the Balek Angin Lake as a protected lake with a value of 0.370 . Based on Fletcher [4], strength in a sustainable environment and clear and supportive regulations are the basis for developing an ecotourism site. Meanwhile, the two aspects with the high weakness value are the presence of waste flowing into the lake (with a score of 0.280 ), and the aspect of lack of supporting facilities (with a score of 0.275 ). This weakness must be overcome by all other supporting factors. Overall, the IFAS score indicates a total score of 2.779.

EFAS analysis showed the highest factor in the opportunity section is the aspect of support from the local government with a score of 0.404 and followed by the aspect of the proximity of the lake to the city center with a score of 0.310 . This opportunity shows that there is great potential to make Lake Balek Balek an ecotourism site. The large lakebed is also the basis of ecotourism development [3]. Whereas the threat factor aspect, which has the highest threat score is the expansion of the Type-C mining area with a score of 0.249 and followed by the aspect of expanding residential area with a score of 0.210 . Overall, the EFAS showed a total score of 2.203 .

The overall value of SWOT analysis from IFAS and EFAS can be illustrated in the SWOT diagram, as shown in Table 3 . The SWOT position shows the value of 2.779: 2.203, which means the strategy taken is a growth strategy by horizontal integration. This strategy requires coordination from various parties involved to achieve the desired goal [12]. This strategy indicates that there are many supporting factors in developing Balek Angin Lake ecotourism compared to its inhibiting factors. This development strategy through horizontal integration also means that the development of ecotourism in Balek Angin Lake must implemented in accordance with the principles of ecotourism [13].

The results of the SWOT analysis were then used to formulate a strategy that will be used in the development of the Balek Angin Lake ecotourism site. This analysis provides conclusions from all the factors that exist so as to produce the basis for developing the Balek Angin Lake ecotourism management strategy. The results of the strategy analysis are displayed in the following Table 4.

The results of the SWOT analysis, in-depth interviews, and field observations were used to formulate the Balek Angin Lake ecotourism development strategy. The strategy must be able to provide maximum benefits to the ecosystem and local communities. The following is the formulation of Balek Angin Lake ecotourism management strategies.

1. Holding joint events tourism at local, regional, and national levels involving local communities, local NGOs, local governments, and funding NGO to protect the ecosystem of Balek Angin Lake

2. Building efforts through cooperation with all relevant parties like Fisheries Agency of Sintang, NGO's which work in fisheries conservation, and so forth to increase the quantity and types of local fish

3. Stipulating a specific regulation to protect the Balek Angin Lake area from environmental damage due to the expansion of community businesses

4. Involvement of local people in managing the ecotourism of Balek Angin Lake so that community income can increase and at the same time reduce the impact of environmental damage due to local community activities

Table 3. Internal Factors Analysis Summary (IFAS) - External Factors Analysis Summary (EFAS) matrix

\begin{tabular}{|c|c|c|c|}
\hline P & High $(3.1-4.0)$ & Medium $(2.1-3.0)$ & $\operatorname{Low}(1.0-2.0)$ \\
\hline High $(3.1-4.0)$ & $\begin{array}{l}\text { GROWTH } \\
\text { Vertical integration strategy }\end{array}$ & $\begin{array}{l}\text { GROWTH } \\
\text { Horizontal } \\
\text { strategy }\end{array}$ & $\begin{array}{l}\text { RETRENCHMENT } \\
\text { Turn-around strategy }\end{array}$ \\
\hline Medium $(2.1-3.0)$ & STABILITY & $\begin{array}{l}\text { GROWTH / STABILITY } \\
\text { horizontal integration } \\
\mathbf{2 . 7 7 9 : 2 . 2 0 3}\end{array}$ & $\begin{array}{l}\text { RETRENCHMENT } \\
\text { Devastation strategy }\end{array}$ \\
\hline Low $(1.0-2.0)$ & $\begin{array}{l}\text { GROWTH } \\
\text { Diversification strategy }\end{array}$ & $\begin{array}{l}\text { GROWTH } \\
\text { Diversification strategy }\end{array}$ & LIQUIDATION \\
\hline
\end{tabular}

Source: Data analysis, 2019. 
Table 4. SWOT Matrix

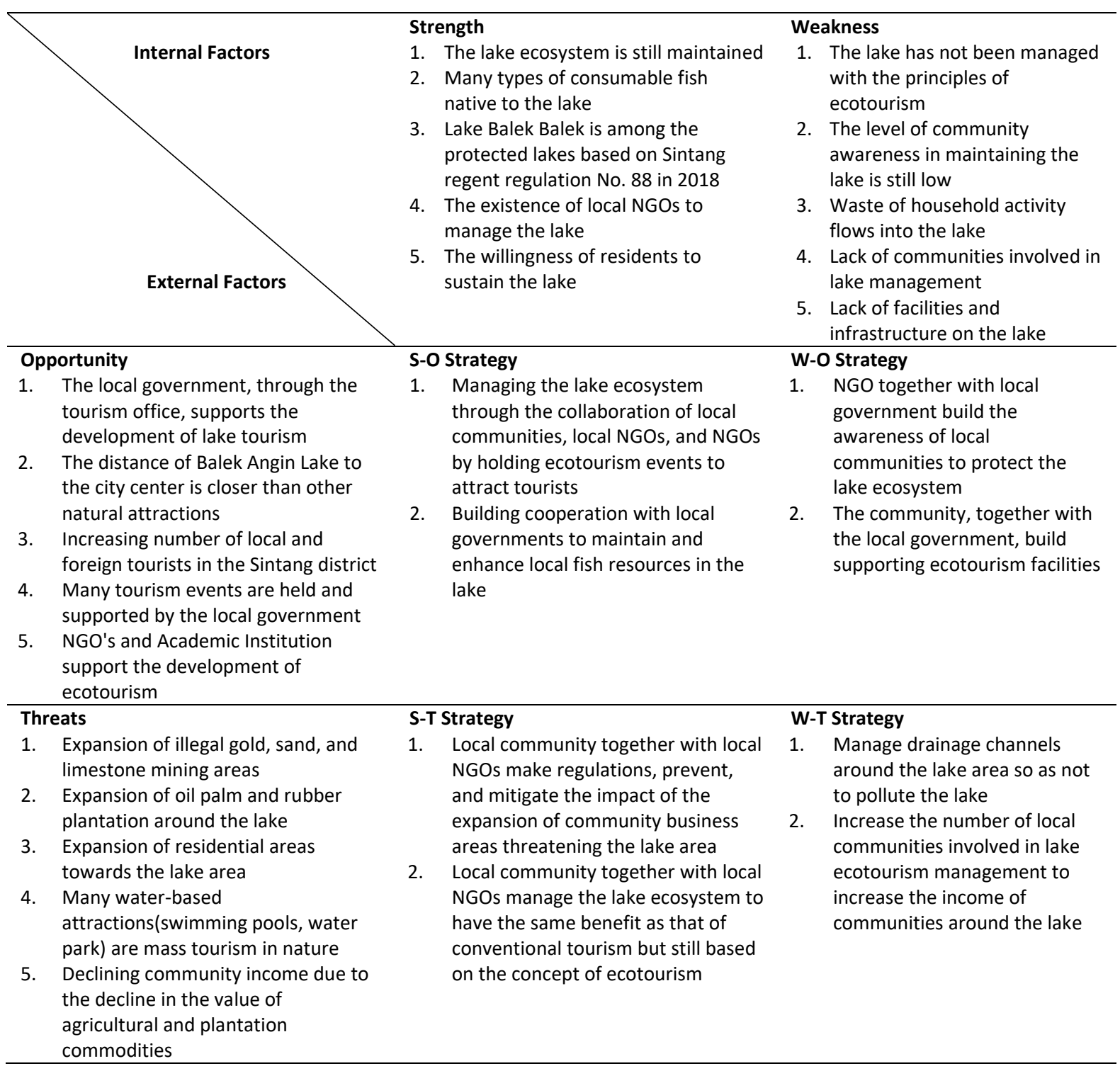

The strategy of developing ecotourism becomes the basis for developing sustainable ecotourism in an area [13]. Ecotourism development that does not have clear regulations may result in natural damage [22,23]. Ecotourism development must also involve as many parties as possible. The development of an ecotourism strategy that involves the parties will increase the chances of a program's success.

In the development of Balek Angin Lake ecotourism, the main focus is the local community. The program to be developed is for the advancement of local communities so that the development strategy must start from the community working together with local NGOs, local governments, NGO funds, and various parties who care about the environment.

\section{CONCLUSION}

In general, the major advantages of Balek Angin Lake as an ecotourism site are the wellpreserved ecosystem, the quantity and types of fish that are still well maintained, the regent's regulation which states that Balek Angin Lake is a protected lake and the presence of local NGO that manages Balek Angin Lake. On the other side, there are also challenges where community activities such as sand mining, oil palm and rubber plantations, community settlements, pollution originating from domestic community activities, and the decline in community income due to falling prices of Sintang Regency's superior commodities have become major threats. The SWOT analysis results show the number 2.779: 2.203 , which means a horizontal integration. It 
means a strategy by coordinating from various parties involved to achieve the desired goal is required. The strategy to developeBalek Angin Lake ecotourism is through the improvement of its ecosystems to its natural condition like releasing the local native fish tillers, involvement of local communities and local government support through the integration of local communities, local NGOs, local governments, NGO funds, local academics and various parties who care about the environment.

\section{Acknowledgement}

The researchers express their gratitude to the Government of Sintang District for the research funding. The researchers also thank the Head of Kelurahan Akcaya 1 and the Head of Jerora Satu village for granting the permit to do research in their neighborhood.

\section{REFERENCES}

[1] BPS-Statistic Center of Sintang Regency. 2017. Sintang Regency in Figures. BPSStatistic Center of Sintang Regency. Sintang.

[2] Chou, M. C. 2013. Does tourism development promote economic growth in transition countries? a panel data analysis. Economic Modelling 33, 226-232.

[3] Mossaz, A., R. C. Buckley, J. G. Castley. 2015. Ecotourism contributions to conservation of African big cats. Journal for Nature Conservation 28, 112-118. DOI: 10.1016/j.jnc.2015.09.009.

[4] Fletcher, R. 2019. Ecotourism after nature: anthropocene tourism as a new capitalist "fix". Journal of Sustainable Tourism 27(4), 522-535.

[5] Kirkby, C. A., R. Giudice-Granados, B. Day, K. Turner, L. M. Velarde-Andrade, A. DuenasDuenas, J. C. Lara-Rivas, D. W. Yu. 2010. The market triumph of ecotourism: an economic investigation of the private and social benefits of competing land uses in the Peruvian Amazon. PLos One 5(9). DOI: 10.1371/journal.pone.0013015.

[6] Rodriguez-Pineros, S. and Y. MayettMoreno. 2015. Forest owners' perception of ecotourism: integrating community values and forest conservation. Ambio 44(2), 99-109. DOI: 10.1007/s13280-0140544-5.

[7] Hashim, R., Z. A. Latif, F. M. Merican, and N. Zamhury. 2015. The Praxis of Langkawi's sustainable regeneration strategy through eco-tourism. Procedia-Social and Behavior
Sciences 170, 49-57. DOI: 10.1016/j.sbspro. 2015.01.014.

[8] Decenly, D., Soeprobowati, T.R., Muhammad, F. 2014. Potensi ekowisata danau di Kawasan Kamipang Kalimantan Tengah. Biosaintifika 6(2), 111-121.

[9] Prasetyo, N. J. and E. Saptutyningsih. 2013. Bagaimana kesediaan untuk membayar peningkatan kualitas lingkungan desa wisata? Jurnal Ekonomi dan Studi Pembangunan 14(2), 127-136.

[10] Hultman, M., A. Kazeminia, and V. Ghasemi. 2015. Intention to visit and willingness to pay premium for ecotourism: the impact of attitude, materialism, and motivation. Journal of Business Research 68, 18541861. DOI: 10.1016/j.jbusres.2015.01.013.

[11] Setiawan, H. 2017. Nepenthes as tourism flagship species: the conservation strategies in Dayak Seberuang Settlements Area. Journal of Indonesian Tourism and Development Studies 5(2), 113-120. DOI: 10.21776/ub.jitode.2017.005.02.07.

[12] Rangkuti, F. 2013. Analisis SWOT: teknik membedah kasus bisnis. Gramedia Pustaka Utama. Jakarta.

[13] Ghorbani, A., V. Raufirad, P. Rafiaani, and H. Azadi. 2015. Ecotourism sustainable development strategies using SWOT and QSPM model: a case study of Kaji Namakzar Wetland, South Khorasan Province, Iran. Tourism Management Perspectives 16, 290297. DOI: 10.1016/j.tmp.2015.09.005.

[14] Jaber, J. O., F. Eikarmi, E. Alasis, and A. Kostas. 2015. Employment of renewable energy in Jordan: current status, SWOT and problem analysis. Renewable and Sustainable Energy Reviews 49, 490-499. DOI: 10.1016/j.rser.2015.04.050

[15] Adjie, S., and A. S. Utomo, 2017. Karakteristik habitat dan sebaran jenis ikan di Sungai Kapuas bagian tengah dan hilir. BAWAL 3(5), 277-286.

[16] Ng, C. K., P. A. Oii, W. L. Wong, and G. Khoo. 2017. An overview of the status, trends and challenges of Freshwater Fish Research and Conservation in Malaysia. Journal of Survey in Fisheries Sciences 3(2), 7-21.

[17] Giesen, W. and G. Z. Anshari. 2016. Danau Sentarum National Park (Indonesia). In: Finlayson, C., G. Milton, R. Prentice, N. Davidson (Eds). The Wetland Book. Springer, Dordrecht. DOI: 10.1007/978-94007-6173-5_44-2. 
[18] Adalina, Y. 2018. Analisis habitat koloni lebah hutan Apis dorsata dan kualitas madu yang dihasilkan dari kawasan hutan denga tujuan khusus yang dihasilkan dari Kawasan Hutan dengan Tujuan Khusus (KHDTK) Rantau, Kalimantan Selatan. Jurnal Penelitian Hutan dan Konservasi Alam 15(1), 25-40.

[19] Yonda, D. R. 2016. Social transformation on traditional society (case study on Dayak Iban Society of Kapuas Hulu, Kalimantan Barat). International Conference on Ethics of Business, Economics, and Society Science, 452-460.

[20] Yusnikusumah, T. R. and E. Sulystiawati. 2016. Evaluasi pengelolaan ekowisata di Kawasan Ekowisata Tangkahan Taman Nasional Gunung Leuser Sumatera Utara. Jurnal Perencanaan Wilayah dan Kota 27(3), 173-189.

[21] Hakim, L. 2017. Managing biodiversity for a competitive ecotourism industry in tropical developing countries: new opportunities in biological fields. AIP Conference Proceedings 1908, $030008 . \quad$ DOI: doi.org/10.1063/1.5012708.

[22] Nasution, R. H., R. Avenzora, and T. Sunarminto. 2018. Analisis kebijakan dan peraturan perundang-undangan ekowisata di Indonesia. Media Konservasi 23(1), 9-17.

[23] Rhama, B. 2018. The analysis of the Central Kalimantan tourism development plan based on ecotourism policy perspective. Policy \& Governance Review 2(3), 204-016. DOI: doi.org/10.30589/pgr.v2i3.110.

[24] Tropical Plants Database, Ken Fern. tropical.theferns.info. 2019-08-29. Available at: <tropical.theferns.info/viewtropical.php ?id=Barringtonia+acutangula $>$. 